\title{
Assessment of Chemical Properties of Soil under Different Land use Systems in a Mollisol
}

\author{
Varsha Pandey*, Poonam Gautam and A.P. Singh
}

Department of Soil Science, College of Agriculture, G B Pant University of Agriculture and Technology, Pantnagar 263145, Uttarakhand, India

*Corresponding author

\section{A B S T R A C T}

\section{Keywords}

Chemical, properties, Land use systems, Mollisol

Article Info

Accepted:

10 October 2019

Available Online:

10 November 2019
The present study was undertaken during Kharif 2017-18 to assess chemical properties of soil under different land use systems in a Mollisol. The study area was located at Norman E. Borlaug Crop Research Centre, G. B. Pant University of Agriculture and Technology, Pantnagar. The land use systems selected for study were rice-wheat-green gram, ricepea(vegetable)-maize, rice-potato -okra, rice-berseem + oat + mustard(fodder)-maize + cowpea(fodder), maize-wheat-cowpea, sorghum(fodder)-yellow sarson-black gram, guava + lemon, poplar + turmeric, eucalyptus + turmeric and fallow(uncultivated land). Soil samples were taken from $0-20 \mathrm{~cm}$ depth and analyzed for the various chemical properties. Soil $\mathrm{pH}\left(\mathrm{H}_{2} \mathrm{O}\right)$ varied from 7.38 to 7.49 , electrical conductivity varied from 0.249 to 0.326 $\mathrm{dSm}^{-1}$ and CEC varied from 22.21 to $36.51 \mathrm{C} \operatorname{mol}(\mathrm{p}+) \mathrm{kg}^{-1}$ soil. Soil organic carbon content ranged from 0.54 to 1.52 percent. Available soil nitrogen content varied from 148.02 to $311.09 \mathrm{~kg} \mathrm{ha}^{-1}$, available soil phosphorus from 14.29 to $25.97 \mathrm{~kg} \mathrm{ha}^{-1}$ and available soil potassium from 153.66 to $259.62 \mathrm{~kg} \mathrm{ha}^{-1}$. Available sulphur varied from 16.99 to $32.03 \mathrm{mg} \mathrm{kg}^{-1}$. Among micronutrients, available zinc content in soil varied from 0.77 to $2.16 \mathrm{mg} \mathrm{kg}^{-1}$, available copper content in soil from 3.83 to $5.89 \mathrm{mg} \mathrm{kg}^{-1}$, available iron content in soil from 14.07 to $33.84 \mathrm{mg} \mathrm{kg}^{-1}$ and available Mn content in soil from 5.93 to $7.89 \mathrm{mg} \mathrm{kg}$. . Results indicated that with respect to chemical properties of soil agroforestry based systems were found superior followed by field crops, horticultural crops and the fallow (uncultivated land).

\section{Introduction}

Chemical property of soil is an index of availability of nutrients and a function of various processes occurring in the soil. Chemical properties not only reflect the capacity of soil to provide congenial chemical and nutritional environment to plants but also supports biological and physical processes in soil.

Lal (2003) stated that soil is a significant long term reservoir of organic carbon and play a significant role in the global carbon cycle. But, cultivation exposes organic matter to a greater rate of decay and oxidation (Young 
and Young, 2001) resulting in low total nitrogen content (Havlin et al., 2000). Cropping systems can affect a range of soil properties depending on the specific crop rotation, nutrient amendments, and tillage practices employed (Masto et al., 2007). Over the time, this can result in soil quality degradation, improvement, or being maintained (Jokela et al., 2009).

A better understanding of the impact of continuous crop rotations on chemical properties of soil is essential for evaluation of soil quality and thereby enhancing cropping system sustainability (Aparicio and Costa, 2007).

Present study was undertaken to assess the chemical properties of soil under different land use systems in a Mollisol.

\section{Materials and Methods}

The study area was located at Norman E. Borlaug Crop Research Centre, G. B. Pant University of Agriculture and Technology, Pantnagar. Five composite soil samples (0-20 $\mathrm{cm}$ depth) representing the whole area were collected randomly from different land use systems comprising of field crops, horticultural crops, agroforestry crops and fallow (uncultivated land) of the same block during kharif, 2017-18. Each composite soil sample was processed and used for the analysis of chemical properties.

Soil $\mathrm{pH}$ and EC were analysed by soil water suspension (1:2) (Jackson, 1967). Soil Organic carbon by Walkley and Black (1934) method.

CEC was analysed by Bache (1976) method. Available nitrogen content in soil was analysed by Subbiah and Asija (1956) method, available phosphorus in soil by Olsen et al., (1954), available potassium in soil by Black (1965), available sulphur content by Williams and Steinbergs (1959) and available micronutrients was analysed by Lindsay and Norvell (1978) method.

The data were analysed statistically by using complete randomized design (C.R.D). The data collected on different soil properties were analysed applying ANOVA technique (Pansa and Sukhatme, 1985). The overall difference was tested by $\mathrm{F}$ test of significance at $5 \%$ level of probability. In case of significant $\mathrm{F}$ test, C.D. at $5 \%$ was calculated for comparing treatment means.

\section{Results and Discussion}

\section{Soil pH}

The $\mathrm{pH}\left(\mathrm{H}_{2} \mathrm{O}\right)$ of a soil indicates the degree of availability of plant nutrients and lime requirement of the soil. A number of soil fertility characters can be concluded from the soil $\mathrm{pH}$ (Landon, 1991). The data pertaining to the soil $\mathrm{pH}$ significantly differed under different land use systems and varied from 7.38 to 7.49 (Table 1). Lowest soil $\mathrm{pH}$ was recorded under eucalyptus + turmeric system which was significantly lower than the soil $\mathrm{pH}$ noted under all other systems except poplar + turmeric and rice-potato okra land use system. Soil $\mathrm{pH}$ noted under maize-wheat-cowpea and fallow (uncultivated) land was significantly lower than that of guava + lemon system.

Lowest soil $\mathrm{pH}$ was seen under agroforestry system i.e. eucalyptus + turmeric followed by poplar + turmeric system which might be due to high organic carbon content. The results are similar to the findings of Kumar (2015). The decomposition of organic matter released organic acids which lowered down the soil $\mathrm{pH}$. Highest soil $\mathrm{pH}$ was seen under guava + lemon system. Similar results were also obtained by Ekka et al., (2017) in case of guava based system. 
Since the change in the $\mathrm{pH}$ are mainly because of the parent material and climate under which the soil formation takes place therefore very little changes in soil $\mathrm{pH}$ are observed within adjacent area or area of a few hectares. In this study all the sampling sites were adjacent to each other which might have resulted in the least variation in $\mathrm{pH}$. Similar observations were also reported by Cox et al., (2003) and Shukla et al., (2004).

$\mathrm{pH}(\mathrm{KCl})$ significantly varied under different land use systems and ranged from 5.68 to 6.55. Lowest $\mathrm{pH}(\mathrm{KCl})$ and highest $\mathrm{pH}(\mathrm{KCl})$ was noted under eucalyptus + turmeric and fallow (uncultivated) land use system respectively. $\mathrm{pH}(\mathrm{KCl})$ recorded under eucalyptus + turmeric system was significantly lower than the $\mathrm{pH}$ noted under poplar + turmeric, rice-potato -okra, ricewheat-green gram, rice-berseem + oat + mustard (fodder) - maize + cowpea(fodder), sorghum (fodder) - yellow sarson-black gram, rice-pea (vegetable) - maize, maize-wheatcowpea, guava + lemon and fallow (uncultivated) land use system. $\mathrm{pH}(\mathrm{KCl})$ recorded under poplar + turmeric and ricepotato -okra system was significantly lower than that under rice-wheat-green gram, riceberseem + oat + mustard (fodder) - maize + cowpea (fodder), sorghum (fodder) - yellow sarson-black gram, rice-pea (vegetable) maize, maize-wheat-cowpea, guava + lemon and fallow(uncultivated) land use system. $\mathrm{pH}$ $(\mathrm{KCl})$ under maize-wheat-cowpea system was significantly lower than that under fallow (uncultivated) land use system. In the present study, $\mathrm{pH}(\mathrm{KCl})$ was slightly lower than $\mathrm{pH}$ $\left(\mathrm{H}_{2} \mathrm{O}\right)$. Similar observations were made by Ramzan (2013).

Delta $\mathrm{pH}$ varied significantly under different land use systems and it ranged from 0.92 (under fallow) to 1.70 (under eucalyptus + turmeric) (Table 1). Delta $\mathrm{pH}$ recorded under fallow land use system was significantly lower than the delta $\mathrm{pH}$ noted under all other systems except guava + lemon system. Delta $\mathrm{pH}$ noted under guava + lemon system was significantly lower than the delta $\mathrm{pH}$ noted under sorghum(fodder)-yellow sarson-black gram, rice-berseem + oat + mustard(fodder)maize + cowpea (fodder), rice-wheat-green gram, rice-potato-okra, poplar + turmeric and eucalyptus + turmeric land use system.

Delta $\mathrm{pH}$ noted under rice-potato - okra system was significantly lower than that under eucalyptus + turmeric system.

Since the value of $\mathrm{pH}\left(\mathrm{H}_{2} \mathrm{O}\right)$ is greater than $\mathrm{pH}$ $(\mathrm{KCl})$, delta $\mathrm{pH}$ values remained positive which is an indication of presence of negatively charged clay surface. Gurmessa (2002) also reported that when $\mathrm{pH}\left(\mathrm{H}_{2} \mathrm{O}\right)$ is higher than $\mathrm{pH}(\mathrm{KCl})$, the soil is dominated with layer of silicate minerals and oxides of iron and aluminum. Soil $\mathrm{pH}(\mathrm{KCl})$ indicates the potential acidity and presence of weatherable minerals when the difference of soil $\mathrm{pH}\left(\mathrm{H}_{2} \mathrm{O}\right)$ and $\mathrm{pH}(\mathrm{KCl})$ is greater than unity (Buol et al., 2003).

\section{Electrical conductivity}

Electrical conductivity of soil significantly differed under different land use systems. It ranged from 0.249 to $0.326 \mathrm{dSm}^{-1}$ (Table 1). Lowest value of electrical conductivity was recorded under fallow (uncultivated) land use system which was significantly lower than that noted under rice-berseem + oat + mustard (fodder)-maize +cowpea (fodder), rice-potato -okra, sorghum (fodder)-yellow sarson-black gram, rice-pea (vegetable)-maize, maizewheat-cowpea, rice-wheat-green gram, eucalyptus + turmeric and poplar + turmeric land use system. Electrical conductivity recorded under rice-potato-okra, sorghum (fodder)-yellow sarson-black gram and ricepea (vegetable)-maize system was significantly lower than that under maize- 
wheat-cowpea, rice-wheat-green gram, eucalyptus + turmeric and poplar + turmeric land use system. Higher electrical conductivity under agroforestry system i.e. poplar + turmeric followed by eucalyptus + turmeric system was due to high organic carbon content. This might be due to the decomposition of organic matter (Larson and Pierce, 2002 and Nayak et al., 2017). There was a significant increase in EC values under cultivated soils over uncultivated fallow land.

This might be due to irrigation, fertilizers and accumulation of salts in the root zone because of movement of soil solution under the influence of transpiration pull from sub surface of soil by dense crops and leaving the salts in the root zone (Tiwari et al., 1995).

\section{Cation exchange capacity}

Cation exchange capacity of soil significantly differed under different land use systems and varied from 22.21 to $36.51 \mathrm{Cmol}(\mathrm{p}+) \mathrm{kg}^{-1}$ soil (Table 1). Highest value of CEC was recorded under eucalyptus + turmeric system which was significantly higher than that under all other land use systems. CEC of soil noted under poplar + turmeric system was significantly higher than it was noted under rice-potatookra, rice-berseem + oat + mustard(fodder)maize + cowpea(fodder), rice-wheat-green gram, sorghum (fodder)-yellow sarson-black gram, rice-pea (vegetable)-maize, maizewheat-cowpea, guava + lemon and fallow(uncultivated) land use system. CEC registered under guava + lemon system was significantly higher than that noted under fallow (uncultivated) land use system.

The higher CEC under agroforestry system i.e. eucalyptus + turmeric followed by poplar + turmeric was observed which might be due to high organic matter and clay content. Similar findings were also reported by Swaranam et al., (2004).

\section{Soil organic carbon}

Organic carbon content significantly differed under different land use systems and varied from $0.54 \%$ to $1.52 \%$ (Table 2). Soil organic carbon content was recorded highest under eucalyptus + turmeric system which was significantly higher than the soil organic carbon content recorded under all other land use systems. Soil organic carbon content noted under poplar + turmeric system was significantly higher than that under ricepotato-okra, rice-berseem + oat + mustard (fodder)-maize + cowpea (fodder), ricewheat-green gram, sorghum (fodder)-yellow sarson-black gram, rice-pea (vegetable)maize, maize-wheat-cowpea, guava + lemon and fallow (uncultivated) land use system. Soil organic carbon noted under guava + lemon system was significantly higher than it was under fallow (uncultivated) land use system.

Higher soil organic carbon was reported under agroforestry based system i.e. eucalyptus + turmeric followed by poplar + turmeric. While, among the field crops, organic carbon followed the order: Rice-potato-okra > riceberseem + oat + mustard (fodder)-maize + cowpea (fodder) > rice-wheat-green gram > sorghum(fodder)-yellow sarson-black gram in the present study. The superiority of agroforestry based systems (i.e. eucalyptus + turmeric followed by poplar + turmeric) over other land use systems might be due to dense canopy which lead to more nutrient accretion in the soil by minimizing the loss through soil erosion and leaching. Besides, enhanced litter production and congenial temperature for microbes. While among field crops based systems, rice-potato-okra was found better as compared to other field crops based systems might be due to higher soil organic carbon content. Least soil organic carbon content under fallow land might be due to poor vegetative cover and frequent cutting of the 
grasses and weeds from the soil surface. Comparatively higher organic carbon content in the forest based cropping system might be due to litter fall of the trees on the soil surface as reported by Singh et al., (2006) and Patil and Prasad (2004).

The lowest organic carbon was observed in the maize based cropping system among the cereals which might be due to more exhaustive cropping system (Yadda, 2007). Significant increase in the soil organic carbon content under cultivated soils over the uncultivated soils was observed. This might be attributed to the addition of crop residues and organic manures in the cultivated soils (Tiwari et al., 1995).

\section{Available soil nitrogen}

Available nitrogen content was significantly affected by different land use systems and ranged from 148.02 to $311.09 \mathrm{~kg} \mathrm{ha}^{-1}$ at $0-20$ $\mathrm{cm}$ depth (Table 2). Soil available nitrogen content was recorded highest under eucalyptus + turmeric system which was significantly higher than the available soil nitrogen reported under all other land use systems.

Table.1 $\mathrm{pH} \mathrm{H}_{2} \mathrm{O}, \mathrm{pH} \mathrm{KCl}$, delta $\mathrm{pH}, \mathrm{EC}$, and $\mathrm{CEC}$ of soil under different land use systems

\begin{tabular}{|c|c|c|c|c|c|}
\hline Land use systems & pH $\mathrm{H}_{2} \mathrm{O}$ & pH KCl & delta pH & $\begin{array}{c}\mathrm{EC} \\
\left(\mathrm{dsm}^{-1}\right)\end{array}$ & $\begin{array}{c}\text { CEC } \\
\left(\mathrm{cmol}^{+}\left(\mathbf{p}^{+}\right)\right. \\
\left.\mathrm{kg}^{-1} \text { soil }\right)\end{array}$ \\
\hline Rice - wheat - green gram & 7.42 & 5.99 & 1.43 & 0.312 & 30.90 \\
\hline Rice - pea (vegetable) -maize & 7.44 & 6.32 & 1.12 & 0.292 & 29.08 \\
\hline Rice - potato - okra & 7.41 & 5.87 & 1.54 & 0.283 & 33.37 \\
\hline $\begin{array}{l}\text { Rice }- \text { berseem + oat + mustard } \\
\text { (fodder) -maize+cowpea (fodder) }\end{array}$ & 7.43 & 6.16 & 1.27 & 0.260 & 32.68 \\
\hline Maize - wheat - cowpea & 7.45 & 6.40 & 1.05 & 0.307 & 28.02 \\
\hline $\begin{array}{c}\text { Sorghum (fodder) - yellow sarson - } \\
\text { black gram }\end{array}$ & 7.44 & 6.23 & 1.21 & 0.290 & 30.53 \\
\hline Guava + lemon & 7.49 & 6.46 & 1.02 & 0.258 & 26.29 \\
\hline Poplar + turmeric & 7.40 & 5.79 & 1.61 & 0.326 & 35.63 \\
\hline Eucalyptus + turmeric & 7.38 & 5.68 & 1.70 & 0.316 & 36.51 \\
\hline Fallow (uncultivated land) & 7.47 & 6.55 & 0.92 & 0.249 & 22.21 \\
\hline SEm \pm & 0.012 & 0.035 & 0.038 & 0.003 & 0.25 \\
\hline CD at $5 \%$ & 0.035 & 0.101 & 0.107 & 0.011 & 0.72 \\
\hline
\end{tabular}


Table. 2 Soil organic carbon, available nitrogen, available phosphorus, available potassium, available sulphur, and micronutrients content in soil under different land use systems at $0-20$ cm depth

\begin{tabular}{|c|c|c|c|c|c|c|c|c|c|}
\hline $\begin{array}{l}\text { Land use } \\
\text { systems }\end{array}$ & $\begin{array}{c}\text { Soil } \\
\text { organic } \\
\text { carbon } \\
(\%)\end{array}$ & $\begin{array}{c}\text { Available } \\
\mathbf{N} \\
\left(\mathrm{kg} \mathrm{ha}^{-1}\right)\end{array}$ & $\begin{array}{c}\text { Available } \\
\mathbf{P} \\
\left(\mathrm{kg} \mathrm{ha}^{-1}\right)\end{array}$ & $\begin{array}{c}\text { Available } \\
\text { K } \\
\left(\mathbf{k g ~ h a} \mathbf{~}^{\mathbf{1}}\right)\end{array}$ & $\begin{array}{c}\text { Available } \\
\text { S } \\
\left(\mathrm{mg} \mathrm{kg}^{-1}\right)\end{array}$ & $\begin{array}{c}\mathbf{Z n} \\
(\mathbf{m g} \\
\left.\mathbf{k g}^{-1}\right)\end{array}$ & $\begin{array}{c}\mathbf{C u} \\
(\mathbf{m g} \\
\left.\mathbf{k g}^{-1}\right)\end{array}$ & $\begin{array}{c}\mathbf{F e} \\
(\mathbf{m g} \\
\left.\mathbf{k g}^{-1}\right)\end{array}$ & $\begin{array}{r}\mathbf{M n} \\
(\mathbf{m g} \\
\left.\mathbf{k g}^{-1}\right)\end{array}$ \\
\hline $\begin{array}{l}\text { Rice - wheat - } \\
\text { green gram }\end{array}$ & 1.13 & 248.37 & 24.51 & 217.28 & 26.05 & 1.85 & 4.53 & 23.16 & 7.12 \\
\hline $\begin{array}{c}\text { Rice - pea } \\
\text { (vegetable) - } \\
\text { maize }\end{array}$ & 1.04 & 220.77 & 21.13 & 210.11 & 21.09 & 1.71 & 4.34 & 21.22 & 6.67 \\
\hline $\begin{array}{c}\text { Rice - potato } \\
\text { - okra }\end{array}$ & 1.27 & 283.49 & 24.97 & 229.82 & 28.51 & 1.94 & 5.10 & 27.02 & 7.17 \\
\hline $\begin{array}{c}\text { Rice - } \\
\text { berseem + oat } \\
+ \text { mustard } \\
\text { (fodder) - } \\
\text { maize+cowpea } \\
\text { (fodder) }\end{array}$ & 1.20 & 265.93 & 24.28 & 228.93 & 27.97 & 1.98 & 4.71 & 27.63 & 7.52 \\
\hline $\begin{array}{c}\text { Maize - wheat } \\
\text { - cowpea }\end{array}$ & 1.01 & 213.25 & 21.75 & 196.90 & 20.82 & 1.49 & 4.92 & 18.11 & 6.36 \\
\hline $\begin{array}{c}\begin{array}{c}\text { Sorghum } \\
\text { (fodder) - }\end{array} \\
\text { yellow sarson } \\
\text { - black gram }\end{array}$ & 1.13 & 238.34 & 21.52 & 220.64 & 24.26 & 1.65 & 4.75 & 20.15 & 6.90 \\
\hline $\begin{array}{c}\text { Guava + } \\
\text { lemon }\end{array}$ & 0.80 & 205.72 & 18.06 & 186.82 & 20.59 & 1.31 & 4.14 & 17.15 & 6.11 \\
\hline $\begin{array}{l}\text { Poplar + } \\
\text { turmeric }\end{array}$ & 1.40 & 298.55 & 25.67 & 239.23 & 30.66 & 2.07 & 5.67 & 30.51 & 7.71 \\
\hline $\begin{array}{c}\text { Eucalyptus + } \\
\text { turmeric }\end{array}$ & 1.52 & 311.09 & 25.97 & 259.62 & 32.03 & 2.16 & 5.89 & 33.84 & 7.89 \\
\hline $\begin{array}{c}\text { Fallow } \\
\text { (uncultivated } \\
\text { land) }\end{array}$ & 0.54 & 148.02 & 14.29 & 153.66 & 16.99 & 0.77 & 3.83 & 14.07 & 5.93 \\
\hline SEm \pm & 0.01 & & 0.44 & 1.64 & 0.16 & 0.015 & 0.025 & 0.43 & 0.042 \\
\hline CD at $5 \%$ & 0.04 & 10.01 & 1.25 & 4.69 & 0.46 & 0.045 & 0.071 & 1.24 & 0.12 \\
\hline
\end{tabular}

Available soil nitrogen reported under poplar + turmeric system was significantly higher than that under rice-potato -okra, rice-berseem + oat + mustard (fodder)-maize + cowpea(fodder), rice-wheat-green gram, sorghum(fodder)-yellow sarson-black gram, rice-pea (vegetable)-maize, maize-wheatcowpea, guava + lemon and fallow (uncultivated) land use system. Available soil nitrogen noted under maize-wheat-cowpea and guava + lemon system was significantly higher that under fallow (uncultivated) land 
use system. Higher availability of soil nitrogen under eucalyptus + turmeric system poplar + turmeric system might be due to high water holding capacity, porosity and organic carbon which helped in the mineralization of soil nitrogen leading to buildup of higher available nitrogen. Kumar (2015) reported that organic carbon is considered as an index of available nitrogen content of soils. Tisdale et al., (1995) also reported that total $\mathrm{N}$ content of a soil is directly associated with organic carbon content. Srivastava et al., (2015) reported relatively lower value of available soil nitrogen in fruit based cropping system as fruits are nutrient exhaustive and highly effective in nutrient mining from the soil.

\section{Available soil phosphorus}

The available phosphorus content in soil varied significantly under different land use systems and varied from 14.29 to $25.97 \mathrm{~kg}$ $\mathrm{ha}^{-1}$ (Table 2). The highest value of available soil phosphorus was recorded under eucalyptus + turmeric followed by poplar + turmeric and rice-potato-okra system. Available soil phosphorus under eucalyptus + turmeric and poplar + turmeric system was significantly more than noted under ricewheat-green gram, rice-berseem + oat + mustard (fodder)-maize + cowpea (fodder), maize-wheat-cowpea, sorghum (fodder)yellow sarson-black gram, rice-pea (vegetable)-maize, guava + lemon and fallow(uncultivated) land use system. Available soil phosphorus noted under guava + lemon system was found significantly higher than that under fallow (uncultivated) land use system. Yadda et al., (2007) observed that with increase in the organic carbon content of the soil, the available phosphorus increases because of its fast mineralization in agroforestry systems. The phosphorus content under cultivated land use systems was significantly higher over fallow (uncultivated) land use system. This might be because of phosphate fertilization and accumulation of phosphorus. Soils under field crops land use systems with pulse cropping showed relatively lower value of available phosphorus than that under other land use systems.

This might be due to the fact that legumes utilize more phosphorus thereby depleting the phosphorus content in the soils (Tiwari et al., 1995).

\section{Available soil potassium}

Available potassium content in soil differed significantly under different land use systems and varied from 153.66 to $259.62 \mathrm{~kg} \mathrm{ha}^{-1}$ (Table 2). The highest value of available soil potassium was recorded under eucalyptus + turmeric system which was significantly higher than the values reported under all other land use systems. Available soil potassium noted under poplar + turmeric system was significantly higher than the available soil potassium reported under rice-potato-okra, rice-berseem + oat + mustard (fodder)-maize + cowpea (fodder), sorghum (fodder)-yellow sarson-black gram, rice-wheat-green gram, rice-pea (vegetable)-maize, maize-wheatcowpea, guava + lemon and fallow(uncultivated) land use system. Available soil potassium reported under guava + lemon system was significantly higher than that under fallow (uncultivated) land use system.

Lower value of available potassium under field crop based land use systems than the agroforestry based systems might be due to depletion of potassium either because of vegetation removal or leaching loss. Kumar (2005) and Khongjee (2012) was also of the similar opinion. Results were confirmatory with the findings of Srivastava et al., (2015).

\section{Available soil sulphur}

Available sulphur content in soil differed significantly under different land use systems 
and varied from 16.99 to $32.03 \mathrm{mg} \mathrm{kg}^{-1}$ (Table 2 ). The highest value of available soil sulphur was recorded under eucalyptus + turmeric system which was significantly higher than the value recorded under all other land use systems. Available soil sulphur under poplar + turmeric was significantly higher than the available soil sulphur reported under ricepotato -okra, rice-berseem + oat + mustard(fodder)-maize + cowpea(fodder), rice-wheat-green gram, sorghum(fodder)yellow sarson-black gram, ricepea(vegetable)-maize, maize-wheat-cowpea, guava + lemon and fallow (uncultivated) land use systems. Available soil sulphur observed under maize-wheat-cowpea and guava + lemon system was significantly higher than that under fallow (uncultivated) land use system.

Sharma et al., (2013) observed lower sulphur content under cereal based system which may be due to more exhaustive nature of the cropping system. Higher sulphur content under agroforestry based system might be due to high soil organic carbon content because of recycling which adds to the soil sulphur reserve (Gangola, 2012).

\section{Available soil Zn}

Zinc content in soil differed significantly under different land use systems and varied from 0.77 to $2.16 \mathrm{mg} \mathrm{kg}^{-1}$ (Table 2). Highest value of zinc was recorded under eucalyptus + turmeric system which was significantly higher than the available $\mathrm{Zn}$ noted under all other land use systems. Available $\mathrm{Zn}$ in soil under poplar + turmeric system was significantly higher than under rice-berseem + oat + mustard (fodder)-maize + cowpea(fodder), rice-potato-okra, rice-wheatgreen gram, rice-pea (vegetable) -maize, sorghum (fodder)-yellow sarson-black gram, maize-wheat-cowpea, guava + lemon and fallow (uncultivated) land use system.
Available $\mathrm{Zn}$ in soil found under guava + lemon system was significantly higher than that under fallow (uncultivated) land use system. Highest zinc content under agroforestry based system (i.e. eucalyptus + turmeric and poplar + turmeric) might be due to low $\mathrm{pH}$ and high CEC of the soil. Similar results were also observed by Singh et al., (2006) and Sharma et al., (2013).

\section{Available soil $\mathbf{C u}$}

Available copper content of soil differed significantly under different land use systems and varied from 3.83 to $5.89 \mathrm{mg} \mathrm{kg}^{-1}$ (Table 2 ). Highest value of available copper in soil was recorded under eucalyptus + turmeric system which was significantly higher than the value of available copper noted under all other land use systems. Available $\mathrm{Cu}$ in soil noted under poplar + turmeric system was significantly higher than that under rice-potato -okra, maize-wheat-cowpea, sorghum (fodder) -yellow sarson-black gram, riceberseem + oat + mustard(fodder)-maize + cowpea(fodder), rice-wheat-green gram, ricepea(vegetable)-maize, guava + lemon and fallow(uncultivated) land use system. Available $\mathrm{Cu}$ in soil recorded under guava + lemon system was significantly higher than that under fallow (uncultivated) land use system.

\section{Available soil Fe}

Available iron content in soil significantly varied under different land use systems and ranged from 14.07to $33.84 \mathrm{mg} \mathrm{kg}^{-1}$ (Table 2). Highest value of available iron was recorded under eucalyptus + turmeric system which was significantly higher than the value noted under all other land use systems. Available Fe in soil noted under poplar + turmeric system was significantly higher than that under riceberseem + oat + mustard (fodder)-maize + cowpea (fodder), rice-potato-okra, rice- 
wheat-green gram, rice-pea(vegetable)-maize, sorghum (fodder)-yellow sarson-black gram, maize-wheat-cowpea, guava + lemon and fallow(uncultivated) land use system. Available Fe in soil registered under maizewheat-cowpea and guava + lemon system was significantly higher than that under fallow (uncultivated) land use system.

Higher iron availability under agroforestry based system (i.e. eucalyptus + turmeric and poplar + turmeric) might be due to higher soil organic carbon content under these systems. Sarkar et al., (2001) was also of the similar opinion.

\section{Available soil Mn}

Available $\mathrm{Mn}$ content in soil varied significantly under different land use systems and varied from 5.93to $7.89 \mathrm{mg} \mathrm{kg}^{-1}$ (Table 2). Highest value of $\mathrm{Mn}$ was recorded under eucalyptus + turmeric system which was significantly higher than that under all other land use systems. Available $\mathrm{Mn}$ in soil was noted under poplar + turmeric system was significantly higher than that under riceberseem + oat + mustard(fodder)-maize + cowpea (fodder), rice-potato -okra, ricewheat-green gram, sorghum(fodder)-yellow sarson-black gram, rice-pea(vegetable)-maize, maize-wheat-cowpea, guava + lemon and fallow (uncultivated) land use system. Available $\mathrm{Mn}$ in soil noted under guava + lemon system was significantly higher than fallow (uncultivated) land use system.

Sharma and Chaudhary (2003) reported that DTPA extractable Mn was positively and significantly related to the organic carbon content of the soil which might be the reason of high $\mathrm{Mn}$ content under eucalyptus + turmeric and poplar + turmeric systems.

It can be concluded from the above study that different land use systems have different impact on the soil chemical properties. Results indicated that with respect to chemical properties of soil agroforestry based systems were found superior followed by field crops, horticultural crops and the uncultivated land. It was found that soil organic carbon content has a significant impact on the chemical properties of soil and as a result, soils with higher organic carbon content were rich in available nutrients.

\section{References}

Aparicio, V. and Costa, J. L. 2007. Soil quality indicators under continuous cropping systems in the Argentinean Pampas. Soil and Tillage Research 96(1-2):155-165.

Bache, B.W. 1976. The measurement of cation exchange capacity of soils. Journal of Science of Food and Agriculture 27(3): 273-280.

Black, C.A., 1965. Methods of soil analysis. Part 2. American Society of Agronomy, inc. Madison, Wisconsin, U. S. A. Cox, M. S., Gerard, P. D., Wardlaw, M. C. and Abshire, M. J., 2003. Variability of selected soil properties and their relationships with soybean yield. Soil Science Society of America Journal 67: 1296-1302.

Buol, S.W., R.J. Southard, R.C. Grahm, and P.A. McDaniel. 2003. Soil Genesis and Classification Black Well Pub. Com. Iowa State Press. Fifth edition. Iowa State University press. Ames, USA.

Ekka, A. A., Kumar Dileep Singh., Anand Prakash and Singh Awtar. 2017. Variation in physico-chemical properties of soil under different agri-horti system in Vindhyan region. Journal of Applied and Natural Science 9 (2):1187 - 1193.

Gangola, P., Singh, R., Bhardwaj, A.K. and Gautam, P. 2012. Effect of moog straw on soil properties under INM in longterm rice- wheat cropping system in a Mollisol. International Journal of Agriculture Environment and Biotechnology 5: 281-186. 
Gurmessa Lerissa. 2002, Response of wheat (Triticum aestivum L.) to Fertilizer N and Borana Zone, Ethiopia. Msc Thesis in Agriculture (Agronomy). Alemaya University of agriculture. PP. 35-40.

Havlin, H. L., Beaton, J.D., Tisdale, S. L. and Nelson, W. L., 2000 "Soil Fertility and Fertilizers- an introduction to nutrient management", 7th edition, PHI Learning Private Limited, New Delhi.

Jackson, M.L., 1967. Soil chemical analysis. Prentice Hall of India Pvt. Ltd. New Delhi. pp. 263-293.

Jokela, W. E., Grabber, J. H., Karlen, D. L., Balser, T. C. and Palmquist, D. E., 2009. Cover crop and liquid manure effects on soil quality indicators in a corn silage system. Agronomy Journal. 101:727737.

Khongjee, S. 2012. Runoff and nutrient losses under different land uses in Ga3a microwatershed of Giri river in Solan district of Himachal Pradesh. M.Sc. Thesis, Dr. Y S Parmar University of Horticulture and Forestry, Nauni, Solan. pp.1-79.

Kumar, V. 2005. Erodibility status of soils under different land uses in Shiwalik foothills of district Solan in Himanchal Pradesh. M.Sc. Thesis, Dr. Y S Parmar University of Horticulture and Forestry, Nauni, Solan, 1-88.

Kumar, D. 2015. Assessment of soil quality parameters under different land uses in barog-dhillon watershed in Solan district of Himachal Pradesh. Thesis,MSc. College of forestry, Solan.47p.

Lal, R. 2003. Global potential of soil carbon sequestration to mitigate the greenhouse effect. Critical Reviews in Plant Sciences. 22:151-184.

Landon, J.R. 1991 Booker Tropical Soil Manual: A Hand Book for Soil Survey and Agricultural Land Evaluation with Tropics and Subtropics. Longman Scientific and Technical, Essex, New York. 474p.

Larson, W. E. and Pierce, F. J. 1991. Conservation and enhancement of soil quality in evaluation for sustainable land management in the developing world. Journal of the Indian Society of Soil Science. 2: 17-24.

Lindsay, W.L. and Norvell, W.A. 1978. Development of soil test for zinc, iron, manganese and copper. Soil sci. Soc. American J., 42: 421-428.

Masto, R.E., Chhonkar, P.K., Singh, D. and Patra, A.K. 2007. Soil quality response to long term nutrient and crop management on a semi arid Inceptisol. Agriculture ecosystem and environment 118:130-142.

Nayak, D.R., Y.J. Babu., and T.K. Adhya, 2007. Long-term application of compost influences microbial biomass and enzyme activities in a tropical Aeric Endoaquept planted to rice under flooded condition. Soil Biology and Biochemistry, 39: 1897-1906.

Olsen, S.R., Cole, C.V., Watanabe, F.S. and Dean, L.A. 1954. Estimation of Available phosphorus in soil by Extraction with sodium bicarbonate U.S., Washington; D. C. Circ.: 9:39-49.

Panse, V.G., Sukhatme, P.V. Statistical Methods for Agricultural Workers. Indian Council of Agricultural Research Publication. 1985, 87-89

Patil, R. B. and Prasad, J. 2004. Characteristics and classification of some sal (Shorea robusta) supporting soils in Dindori district of Madhya Pradesh. Journal of Indian Society of Soil Science 52:119125.

Ramzan, S. 2013. Spatial Variability and Mapping of Soil Health Indicators using GIS Techniques. Phd thesis, University of Agricultural Sciences \&Technology of Kashmir 115p.

Sarkar, D, Gangopadhyay, S. K. and Velayutham M. 2001. Soil toposequence relationship and classification in lower outlier of Chhotanagpur plateau. Agropedology 11:29-36.

Sharma, J. C. and Chaudhary, S. K. 2003. verical distribution of micronutrient cations in relation to soil characteristics 
in lower Shiwaliks of Solan district of North-West Himalayas. Journal of Indian Society of Soil Science 55: 40-44.

Sharma Y K, Sharma A and Sharma S K. (2013). An appraisal of physicochemical characteristics and soil fertility status of forest and rice land use systems in Mokokehung district of Nagaland. Journal of the Indian Society of Soil Science 61(1):38-43.

Singh R, Singh K D and Parandiyal A K. 2006. Characterisation and erodibility of soils under different land uses for their management and sustained production. Indian Journal of Soil Conservation 34(3): 226-228.

Srivastava, K., Jat, H.S., Meena, M.D., Chaudhary, M., Mishra, A.K. and Chaudhary, S.K. 2015. Long term impact of different cropping systems on soil quality under silty loam soils of indo-gangetic plains of India. Journal of Applied and Natural Science. 8 (2): 584 $-587$.

Subbiah, B.V. and Asija, G.L. 1956. A Rapid procedure for estimation of available nitrogen in rice soils. Curr. Sci., 25: 259260.

Swaranam T P, Velmurugan A and Rao Y S. (2004). Characterization and classification of some soils from Shahibi basin in parts of Haryana and Delhi. Agropedology 14:114-122.

Tisdale, S. L., Nelson, W. L., Beaton, J. D. and Havlin, J. L. 1995. Soil fertility and fertilizer, 5th Edition Prentice Hall of India, New Delhi. 684 p.

Tiwari, R. C., Verma, U. N. and Mishra, A.K. 1995. Effect of long term cropping system on chemical characteristics of soil profiles. Journal of the Indian Society of Soil Science 43(2): 278-279.

Walkley, A. and Black, C.A. 1934. An examination of Degtjareff method for determining soil organic and a proved modification of chromic acid titration method. Soil Sci., 37: 29-38.

Williams, C.H. and Steinbergs, A. 1959. Soil sulphur fractions as chemical indices of available sulphur in some Australian soils. Australian Journal of Agricultural Research 10: 349-51.

Yadda, T.A. 2007. Effects of fruit based land use systems on soil physicochemical properties: the case of smallholders farming systems in Gamo Gofa, Southern Ethiopia. Thesis, M.Sc. Hawassa university, Awassa, Ethiopia. 49p.

Young, A. and Young, R. 2001. Soils in the Australian Landscape, Oxford University Press, Melbourne.

\section{How to cite this article:}

Varsha Pandey, Poonam Gautam and Singh, A.P. 2019. Assessment Of Chemical Properties of Soil under Different Land use Systems in a Mollisol. Int.J.Curr.Microbiol.App.Sci. 8(11): 1165-1175. doi: https://doi.org/10.20546/ijcmas.2019.811.137 